\title{
STUDIES ON EFFECT OF GIBBERELLIC ACID AND NAPHTHALENE ACETIC ACID SPRAY ON FRUIT SET AND YIELD OF APRICOT (PRUNUS ARMENIACA L.)
}

\author{
NEELAM DEVRARI ${ }^{1}$, MANJU NEG ${ }^{* 2} \&$ NIDHIKA THAKUR ${ }^{3}$ \\ ${ }^{1}$ M.Sc. Student, Department of Fruit Science, VCSG Uttarakhand University of Horticulture and Forestry, \\ Bharsar, Uttarakhand, India \\ ${ }^{2}$ Assistant Professor, Department of Fruit Science, VCSG Uttarakhand University of Horticulture and Forestry, \\ Bharsar, Uttarakhand, India \\ ${ }^{3}$ Assistant Professor, Department of Fruit Science, VCSG Uttarakhand University of Horticulture and Forestry, \\ Bharsar, Uttarakhand, India
}

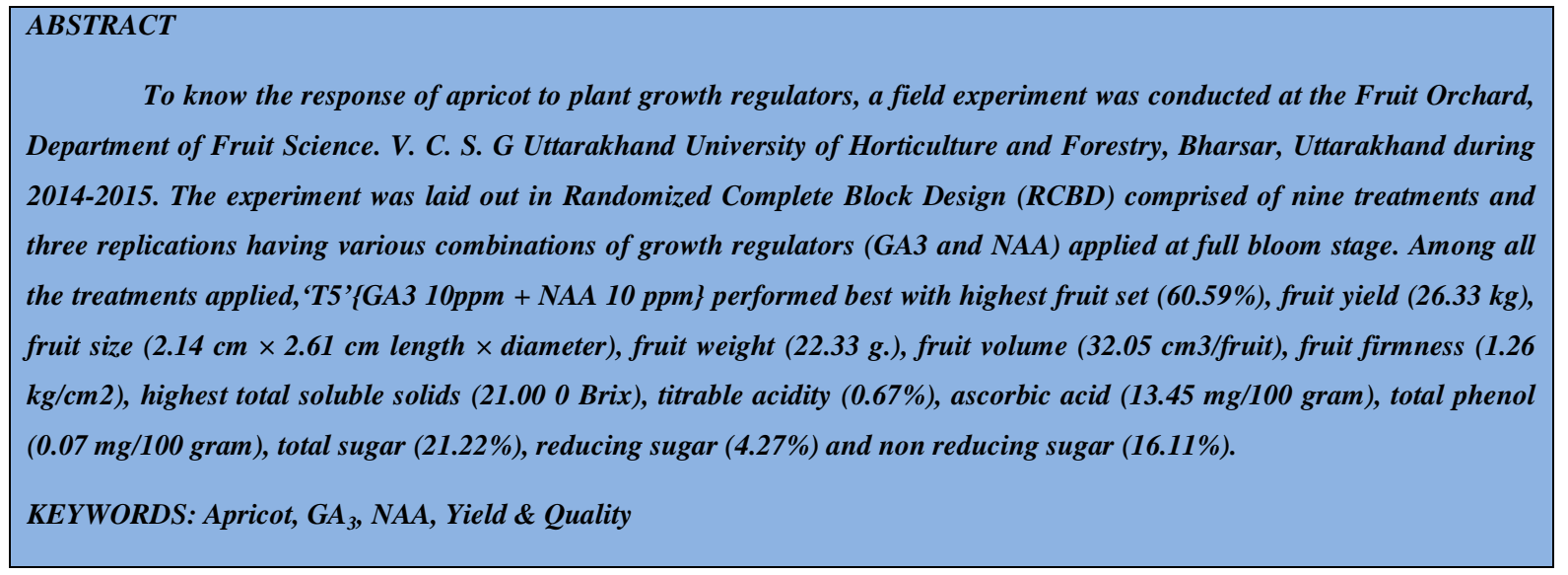

Received: Jan 09, 2017; Accepted: Feb 02, 2017; Published: Jun 28, 2017; Paper Id.: IJASRAUG20178

\section{INTRODUCTION}

Apricot (Prunus armeniaca L.) belonging to family Rosaceous and sub family Prunoidae is one of the members of stone fruits and grown in temperate regions of the world, is one of the most important temperate fruit crops of northeast china region in India. It is liked throughout the world by all the people due to its pleasant taste and nutritional value. Uttarakhand is one of the important states of growing apricot. Plantations of known cultivars are rare and sparse in the state.

Apricot is considered by one of the most delicious temperate tree fruits. The fruit contains different levels of photochemical such as Vitamins, Carotenoids and Polyphenols, which contribute significantly to their taste, color and nutritive value. Generally, apricot fruit has great nutritional value because of fiber, minerals ( $\mathrm{K}, \mathrm{Ca}, \mathrm{Fe}, \mathrm{Mg}, \mathrm{Zn}, \mathrm{P}$ and Se) and low energy intake (50 Kcal $100 \mathrm{~g}-1$ fresh weight) that combined with the nutraceutical plus-value (Vitamin C, A, Carotenoids, Phenols, Thiols, Thiamine, Riboflavin, Niacin and Pantothenic acid) make apricots 'healthy \& easy-toeat' (Leccese et al. 2011). It ranks second next to plum among the stone fruits in area, production and popularity in India.

Plant growth regulators PGRs (auxins, gibberellins, and cytokinins) are used in many fruit production systems to increase fruit size. Preharvest PGR applications that could improve fruit size, color, and precocity of apricot would 
enhance their marketability. The improvement in the yield and quality of the crops, mainly depends on the concentration of plant growth regulator and time of application (Singh, 1995). Bio regulators have used for the improvement of quality and productivity of many fruit crops. Application of gibberellic acid $\left(\mathrm{GA}_{3}\right)$ naphthalene acetic acid (NAA), ethephon separately or in a mixture had a significant effect on fruit set, fruit, dry matter percentage, fruit soluble solid percentage, fruit ripening and yield of fruit crops. Incorporation of growth regulators is a common practice to improve the yield of apricot. If proper care is taken in spray by growth regulators such as $\mathrm{GA}_{3}$ and NAA, the best quality and yield of apricot trees is assured.

\section{MATERIALS AND METHODS}

A field trial was conducted at Fruit Orchard, Department of Fruit Science, V. C. S. G Uttarakhand University of Horticulture and Forestry, Bharsar, Uttarakhand during 2014-2015. The experiment was laid out in Randomized Complete Block Design with nine treatments and three replications. The treatments were as follows: T1: GA 10 ppm, $\mathrm{T}_{2}: \mathrm{GA}_{3} 15$ ppm, T : NAA 10 ppm, T4: NAA 15 ppm, T5: GA 3 10ppm +NAA 10 ppm, T6: GA 15 ppm + NAA 15 ppm, T : GA 10 ppm + NAA $15 \mathrm{ppm}, \mathrm{T}_{8}: \mathrm{GA}_{3} 15 \mathrm{ppm}+\mathrm{NAA} 10 \mathrm{ppm}$ and $\mathrm{T}_{9}$ : control. The spray was applied at full bloom stage in February when the complete flowering was showed on trees. The required amount of PGR was weighted on an electronic digital balance separately, which was dissolved in 50 percent absolute alcohol. The $\mathrm{GA}_{3}$ and NAA 40 and 60 mg single and combined dose were added to 4 liter of water then it will become 10 percent and 15 percent GA 3 and NAA. The spray solutions were prepared in proper concentrations and the final volume was made up with water. Treatment solutions were sprayed on the tree in the morning hours of the day in mist form.

\section{RESULTS AND DISCUSSIONS}

\section{Fruit Set}

The results of the present investigation (Table 1) revealed that a combined application of $\mathrm{GA}_{3}$ 10ppm + NAA 10 ppm increased the fruit set parameters of apricot trees when sprayed at full bloom stage. $\mathrm{GA}_{3} 10 \mathrm{ppm}+\mathrm{NAA} 10$ ppm gave the highest fruit set $(60.59 \%)$ followed by $\mathrm{GA}_{3} 10 \mathrm{ppm}(55.67 \%)$ and the lowest fruit set $(21.38 \%)$ was obtained under control. Similar results were obtained by Shrama and Singh 2008, who found that all the treatments of growth regulators significantly increased the fruit set as compared to control. Findings of the present investigation are also nearly similar to the results of Decker's (1994).

\section{Fruit Yield}

Data presented in Table 2 revealed that GA3 10 ppm +NAA 10 ppm performed best with regard to the fruit yield, which gave highest fruit yield of $26.33 \mathrm{~kg} /$ tree followed by $\mathrm{GA}_{3} 10 \mathrm{ppm}$ with $22.33 \mathrm{~kg} / \mathrm{tree}$ fruit yield. Control with 10.66 $\mathrm{kg}$ fruit per tree obtained the last rank.

The above findings may be correlated with the observations made by Rizk et al., 2006. Plant productivity is dependent upon the interaction between genetic potentialities of the crop plants and the environment in which they grow. 
Table 1: Effect of GA3 and NAA on Fruit Set and Yield

\begin{tabular}{|c|c|c|}
\hline Treatment & Fruit Set $(\%)$ & $\begin{array}{c}\text { Fruit Yield } \\
\text { (kg/tree) }\end{array}$ \\
\hline Control & 21.38 & 10.66 \\
\hline $\mathrm{GA}_{3} 10 \mathrm{ppm}$ & 55.67 & 22.33 \\
\hline $\mathrm{GA}_{3} 15 \mathrm{ppm}$ & 25.05 & 12.33 \\
\hline NAA 10 ppm & 27.16 & 19.66 \\
\hline NAA 15 ppm & 47.57 & 13.00 \\
\hline $\mathrm{GA}_{3} 10 \mathrm{ppm}+\mathrm{NAA} 10 \mathrm{ppm}$ & 60.59 & 26.33 \\
\hline $\mathrm{GA}_{3} 15 \mathrm{ppm}+\mathrm{NAA} 15 \mathrm{ppm}$ & 25.67 & 16.67 \\
\hline $\mathrm{GA}_{3} 10 \mathrm{ppm}+\mathrm{NAA} 15 \mathrm{ppm}$ & 37.67 & 15.00 \\
\hline $\mathrm{GA}_{3} 15 \mathrm{ppm}+\mathrm{NAA} 10 \mathrm{ppm}$ & 36.29 & 18.33 \\
\hline $\mathrm{CD}(0.05)$ & 19.34 & 5.24 \\
\hline
\end{tabular}

\section{FRUIT QUALITY}

\section{Fruit Size}

It is evident from the data of table 2 that, $\mathrm{GA}_{3} 10 \mathrm{ppm}+\mathrm{NAA} 10 \mathrm{ppm}$. The produced biggest fruits $(4.15 \mathrm{~cm}$ length and $4.01 \mathrm{~cm}$ diameter) which was found significantly superior over other treatments followed by $\mathrm{GA}_{3} 10$ ppm $(3.86 \times 3.66$ $\mathrm{L} \times \mathrm{D})$. Smallest fruits $(2.60 \mathrm{~cm}$ length and $2.07 \mathrm{~cm}$ diameter $)$ were produced by the control. The above data are nearly similar to the findings of Negi and Sharma 2003, who reported that, application of NAA stimulate cell enlargement in the fruit mesocarp, which in turn, causes an improvement in fruit size and total yield (Stern et al., 2007). Cleland, 1995 and Ranjan et al., 2003 also reported that the increase in fruit size may be attributed to the increase in cell division and cell elongation caused by NAA and $\mathrm{GA}_{3}$.

\section{Fruit Weight}

Maximum fruit weight was observed in $\mathrm{GA}_{3} 10 \mathrm{ppm}+$ NAA $10 \mathrm{ppm}$ (35.45g) which was statistically at par with NAA $10 \mathrm{ppm}(35.02 \mathrm{~g})$ and $\mathrm{GA}_{3} 10 \mathrm{ppm}(29.36 \mathrm{~g})$. The minimum fruit weight was registered in the control (12.48g).

Table 2: Effect of GA3 and NAA on Fruit Quality

\begin{tabular}{|l|c|c|c|c|c|}
\hline & \multicolumn{2}{|l|}{ Size $(\mathbf{C m})$} & \multirow{2}{*}{ Weight $(\mathbf{G m})$} & Volume $\left(\mathbf{C m}^{\mathbf{3}}\right)$ & Firmness $\left(\mathbf{K g} / \mathbf{C m}^{\mathbf{2}}\right)$ \\
\cline { 2 - 3 } & Length & Diameter & & 25.76 & 0.90 \\
\hline Control & 2.60 & 2.07 & 12.48 & 31.44 & 1.17 \\
\hline $\mathrm{GA}_{3} 10 \mathrm{ppm}$ & 3.86 & 3.66 & 29.36 & 29.98 & 1.16 \\
\hline $\mathrm{GA}_{3} 15 \mathrm{ppm}$ & 3.45 & 3.16 & 21.34 & 30.93 & 1.07 \\
\hline NAA 10 ppm & 3.42 & 3.35 & 35.02 & 28.91 & 1.05 \\
\hline NAA 15 ppm & 3.17 & 3.87 & 24.11 & 32.05 & 1.26 \\
\hline $\mathrm{GA}_{3} 10 \mathrm{ppm}+\mathrm{NAA} 10 \mathrm{ppm}$ & 4.15 & 4.01 & 35.45 & 29.37 & 1.05 \\
\hline $\mathrm{GA}_{3} 15 \mathrm{ppm+NAA} \mathrm{15} \mathrm{ppm}$ & 3.24 & 3.45 & 24.24 & 30.60 & 1.12 \\
\hline $\mathrm{GA}_{3} 10 \mathrm{ppm}+$ NAA 15 ppm & 3.25 & 3.32 & 26.35 & 30.90 & 1.14 \\
\hline $\mathrm{GA} 15 \mathrm{ppm}+$ NAA 10 ppm & 2.65 & 2.79 & 23.47 & 1.20 & 0.11 \\
\hline $\mathrm{CD}(0.05)$ & 0.62 & 0.45 & 7.5 & & \\
\hline
\end{tabular}

\section{Fruit Volume}

A perusal of the data in Table 2 revealed that fruit volume in all treatment varied significantly when the spray was done at the full bloom stage. The highest fruit volume was obtained from $\mathrm{GA}_{3} 10 \mathrm{ppm}+\mathrm{NAA} 10 \mathrm{ppm}\left(32.05 \mathrm{~cm}^{3} / \mathrm{fruit}\right)$ followed by $\mathrm{GA}_{3} 10 \mathrm{ppm}\left(31.44 \mathrm{~cm}^{3} /\right.$ fruit $)$ and the minimum fruit volume was obtained from control $\left(25.76 \mathrm{~cm}^{3} /\right.$ fruit $)$ 
Results of the present study with regards to the fruit weight and volume are close conformity with the findings of Moore (1979) and Wasfy, (1995).

\section{Fruit Firmness}

Data on fruit firmness (Table 2) showed significant effect of different concentrations of $\mathrm{GA}_{3}$ and NAA and revealed that the maximum firmness was obtained from $\mathrm{GA}_{3} 10 \mathrm{ppm}+\mathrm{NAA} 15 \mathrm{ppm}\left(1.26 \mathrm{Kg} / \mathrm{cm}^{2}\right)$ which was found statistically at par with $\mathrm{GA}_{3} 15 \mathrm{ppm}\left(1.16 \mathrm{~kg} / \mathrm{cm}^{2}\right)$ and $\mathrm{GA}_{3} 10 \mathrm{ppm}\left(1.17 \mathrm{~kg} / \mathrm{cm}^{2}\right)$. The minimum firmness was recorded from the control $\left(0.90 \mathrm{~kg} / \mathrm{cm}^{2}\right)$. Increasing fruit firmness is one of the most frequent effects of preharvest GA 3 , and NAA applications in fruit crops (Canli and Orhan, 2009; Kappel and MacDonald, 2002; Stern et al., 2007; Usenik et al., 2005). Results of the present study are more or less match with the findings of these scientists.

\section{Total Soluble Solids}

Total soluble solids showed considerable variations ranging from $16{ }^{0}$ Brix to $21.0{ }^{0}$ Brix, when growth regulators were sprayed at full bloom stage. The data show a significant effect with respect to total soluble solids. The maximum TSS was obtained from $\mathrm{GA}_{3} 10 \mathrm{ppm}+\mathrm{NAA} 10 \mathrm{ppm}\left(21.00{ }^{0} \mathrm{Brix}\right)$ which was statistically at par with $\mathrm{GA}_{3} 10 \mathrm{ppm}\left(20.00^{0} \mathrm{Brix}\right)$. The minimum TSS obtained from control $\left(16.00{ }^{0}\right.$ Brix $)$ which was statistically at par with NAA15 ppm $\left(17.00{ }^{0}\right.$ brix $)$ and $\mathrm{GA}_{3} 15 \mathrm{ppm}+$ NAA $10 \mathrm{ppm}\left(17.00{ }^{0}\right.$ Brix) (Table 3). Results recorded by Sharma and Ananda (2004) nearly similar to the above findings. The results obtained in the present investigation were also found to be in close conformity with the studies of Fazli et al., 2014.

\section{Titratable Acidity}

Titratable acidity considerably varied in all the treatments and showed a range of $0.67 \%$ to $1.18 \%$. The minimum titrable acidity was obtained from $\mathrm{GA}_{3} 10 \mathrm{ppm}+$ NAA $10 \mathrm{ppm}(0.67 \%)$ which was statistically at par with GA 10 ppm $(0.71 \%)$ and $\mathrm{GA}_{3} 10 \mathrm{ppm}+\mathrm{NAA} 15 \mathrm{ppm}(0.73 \%)$ while, the maximum value was obtained in the control (1.18\%) which was significantly higher over the other treatments (Table 3). A similar result was found by Singh and Mishra (1986).

\section{Ascorbic Acid}

Data indicate that different concentrations of $\mathrm{GA}_{3}$ and NAA was found significant, regarding to ascorbic acid content (Table 3). Mean values of ascorbic acid, revealed that treatment $\mathrm{GA}_{3} 10 \mathrm{ppm}+\mathrm{NAA} 10$ ppm possessed maximum ascorbic acid content $(13.45 \mathrm{mg} / 100 \mathrm{~g})$ which was statistically at par with $\mathrm{GA}_{3} 10 \mathrm{ppm}+\mathrm{NAA} 15 \mathrm{ppm}(10.07 \mathrm{mg} / 100 \mathrm{~g})$, $\mathrm{GA}_{3} 10 \mathrm{ppm}(10.35 \mathrm{mg} / 100 \mathrm{~g})$ and NAA $10 \mathrm{ppm}(10.30 \mathrm{mg} / 100 \mathrm{~g})$. In contrast control possessed minimum quantity of ascorbic acid $(9.03 \mathrm{mg} / 100 \mathrm{~g})$. Similar observations were also recorded by Srivastava and Agrawal 1968 who reported that, such a variation in ascorbic acid in different apricot cultivars might be associated with the fruit maturity and the extent of genetic variability as well.

\section{Total Phenol}

Significant variation was found between the treatments with respect to the mean value of total phenol. The maximum value $(0.07 \mathrm{mg} / 100 \mathrm{~g})$ was recorded under $\mathrm{GA}_{3} 10$ ppm+ NAA 10 ppm followed by GA 10 ppm with 0.06 $\mathrm{mg} / 100 \mathrm{~g}$ total phenols. The minimum phenol content was recorded under control $(0.01 \mathrm{mg} / 100 \mathrm{~g})$ (Table 3$)$. 
Table 3: Effect of GA3 and NAA on Fruit Quality

\begin{tabular}{|c|c|c|c|c|c|c|c|}
\hline Treatment & $\begin{array}{c}\text { T S S } \\
\left({ }^{0} \text { Brix }\right)\end{array}$ & $\begin{array}{c}\text { Titrable } \\
\text { Acidity }(\%)\end{array}$ & $\begin{array}{l}\text { Ascorbic } \\
\text { Acid (\%) }\end{array}$ & $\begin{array}{c}\text { Total } \\
\text { Phenol }\end{array}$ & $\begin{array}{c}\text { Total } \\
\text { Sugar } \\
(\%)\end{array}$ & $\begin{array}{c}\text { Reducing } \\
\text { Sugar }(\%)\end{array}$ & $\begin{array}{c}\text { Non } \\
\text { Reducing } \\
\text { Sugar (\%) }\end{array}$ \\
\hline Control & 16.00 & 1.18 & 9.03 & 0.01 & 13.81 & 2.11 & 11.11 \\
\hline $\mathrm{GA}_{3} 10 \mathrm{ppm}$ & 20.00 & 0.71 & 10.35 & 0.06 & 19.73 & 3.70 & 15.22 \\
\hline $\mathrm{GA}_{3} 15 \mathrm{ppm}$ & 18.00 & 0.91 & 9.95 & 0.05 & 18.14 & 2.77 & 14.60 \\
\hline NAA $10 \mathrm{ppm}$ & 16.00 & 0.97 & 10.30 & 0.04 & 15.93 & 3.46 & 11.84 \\
\hline NAA 15 ppm & 17.00 & 0.98 & 9.92 & 0.03 & 15.53 & 3.08 & 11.82 \\
\hline $\mathrm{GA}_{3} 10 \mathrm{ppm}+\mathrm{NAA} 10 \mathrm{ppm}$ & 21.00 & 0.67 & 13.45 & 0.07 & 21.22 & 4.27 & 16.10 \\
\hline $\mathrm{GA}_{3} 15 \mathrm{ppm}+\mathrm{NAA} 15 \mathrm{ppm}$ & 19.00 & 0.85 & 10.07 & 0.03 & 18.26 & 3.25 & 14.23 \\
\hline $\mathrm{GA}_{3} 10 \mathrm{ppm}+\mathrm{NAA} 15 \mathrm{ppm}$ & 19.00 & 0.94 & 9.80 & 0.03 & 19.23 & 3.68 & 14.75 \\
\hline $\mathrm{GA}_{3} 15 \mathrm{ppm}+\mathrm{NAA} 10 \mathrm{ppm}$ & 17.00 & 0.73 & 9.82 & 0.05 & 15.80 & 3.21 & 11.96 \\
\hline $\mathrm{CD}(0.05)$ & 1.729 & 0.158 & 2.203 & 0.020 & 0.883 & 0.586 & 0.685 \\
\hline
\end{tabular}

\section{Total Sugars}

In the present study total sugars of fruits considerably varied from $13.81 \%$ to $21.11 \%$ (Table 3 ). The fruits treated with $\mathrm{GA}_{3} 10 \mathrm{ppm}+\mathrm{NAA} 10 \mathrm{ppm}$ were experienced to be the sweetest and contained highest total sugars (21.22\%) followed by $\mathrm{GA}_{3} 10 \mathrm{ppm}(19.73 \%)$. The minimum (13.81\%) sugar was obtained from control.

\section{Reducing Sugars}

Data on reducing sugar presented in Table 3. The data show that the different concentrations of GA 3 and NAA have a significant effect on reducing sugar. Data regarding reducing sugar content in fruits indicate that $\mathrm{GA}_{3} 10 \mathrm{ppm}+$ NAA 10 ppm treatment had maximum reducing sugar content $(4.27 \%)$ which was statistically at par with GA 10 ppm $(3.70 \%)$ and $\mathrm{GA}_{3} 10 \mathrm{ppm}+\mathrm{NAA} 15 \mathrm{ppm}(3.70 \%)$. Minimum reducing sugar was recorded in the control $2.11 \%$.

\section{Non-reducing Sugars}

In all the treatments studied, non-reducing sugars considerably found significant and showed a range of $11.11 \%$ to $15.69 \%$. Maximum non-reducing sugar was obtained in $\mathrm{GA}_{3} 10 \mathrm{ppm}+$ NAA $10 \mathrm{ppm}(16.10 \%)$ which was statistically at par with $\mathrm{GA}_{3} 10 \mathrm{ppm}(15.22 \%)$ and significantly higher over other treatments. Treatment control had minimum nonreducing sugar content (11.11\%) (Table 3) These findings are in conformity with the results recorded by Westwood (1993).

\section{CONCLUSIONS}

From the present investigation, it is concluded that among various concentrations of $\mathrm{GA}_{3}$ and NAA, GA 10 ppm + NAA 10 ppm and $\mathrm{GA}_{3} 15 \mathrm{ppm}$ + NAA $10 \mathrm{ppm}$ performed the best in terms of percentage of fruit set, fruit yield and quality when sprayed at full bloom stage.

\section{REFERENCES}

1. Canli F A and H Orhan 2009. Effects of pre-harvest gibberellic acid applications on fruit quality of 'O900 Ziraat' sweet cherry. Horticultural Technology. 19:127-129.

2. Cleland CF 1995. Plant Hormones Physiology, Biochemistry and Molecular Biology. P. J. Davies, (Ed). 2nd Edition, Kluwer Academic Publishers, the Netherlands.

3. Decker's $T$ 1994. Camparision between $G A_{3}, G A_{4+7}$ and promalin in fruit setting trials with pear. Fruit teeltnieuws. 7(7):1213. 
4. Fazil SE, Hussein MA, and El- Kassas SE 2014. Effect of some growth regulators on the yield and quality of sweet cheery. Journal of horticulture Science. 69: 653. 664.

5. Kappel $F$ and R A Mac Donald 2002. Gibberellic acid increases fruit firmness, fruit size, and delays maturity of 'Sweetheart' sweet cherry. Journal of American Pomology Society. 56:219-222.

6. Leccese A, Viti R, Bartolini S 2011. The effect of solvent extraction on antioxidant properties of apricot fruit. Central European Journal Biology. 6: 199-204.

7. Moore TC 1979. Biochemistry and Physiology of Plant Hormones. Springer-Verlage, New York, U. S. A.

8. Negi ND and Sharma $N$ 2003. Growth, flowering and cropping response of 'Flemish Beauty' pear to bloom spray of gibberellic acid and benzyl adenine. Act Horticulture. 696: 295-298.

9. Ranjan R, Purohit S S and Prasad V 2003. Plant Hormones: Action and Application. Agro bios, India, pp. 183-189.

10. Rizk-Alla, MS and Meshreki AM 2006. Effect of pre-harvest application of $G A_{3}$, potassium and glucose on fruit quality and storability of Crimson Seedless cultivar. Egypt Journal of Applied Science. 20(6A) 210-238.

11. Sharma and Ananda 2004. Effect of pre-bloom foliar application of plant bio regulators on growth, fruiting, and quality of apple under warmer agro climatic conditions. Act Horticulture. 662: 353-357.

12. Sharma $R R$ and Singh $R$ 2008. GA 3 influence incidence of fruit malformation, berry yield and fruit quality in strawberry (Fragaria x ananassaDuch.). Act Horticulture. 842: 737-740.

13. Singh RP and Mishra SS 1986. Effect of time of harvest and post harvest application of some nutrients, growth regulators and fungicides on storage begaviour of Santa Rosa plum (Prunus salicina L.). M.Sc. Thesis, Himachal Pradesh Krishi Vishva Vidyalaya, Plampur, India.

14. Singh RP 1995. Effect of fall application of $G A_{3}$ and SADH on bloom delay and productivity of apple. Indian Journal of Horticulture. 46 (4): 430-433.

15. Westwood MN 1993. Temperate zone pomology; Physiology and culture, third ed. Timber press, Portland, or, USA, 523pp. 